\title{
Epidemiological Study on Metal Pollution of Ningbo in China
}

\author{
Zhou Li ${ }^{1,+}{ }^{,}$Hong Su ${ }^{1,+}{ }^{+}$Li Wang ${ }^{2,+}$, Danbiao Hu ${ }^{3}$, Lijun Zhang ${ }^{4}$, Jian Fang ${ }^{5}$, Micong Jin ${ }^{2}$,

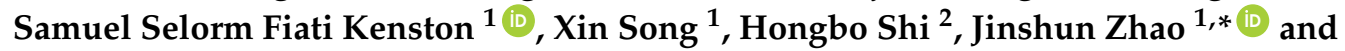 \\ Guochuan Mao ${ }^{2, *}$ \\ 1 Department of Preventative Medicine, Zhejiang Key Laboratory of Pathophysiology, Medicine School of \\ Ningbo University, 818 Fenghua Road, Ningbo 315211, China; lizhou0601@163.com (Z.L.); \\ suhong0908@126.com (H.S.); newsamsel@yahoo.com (S.S.F.K.); songxin3c@163.com (X.S.) \\ 2 Ningbo Centers for Disease Prevention and Control, Ningbo 315010, China; ningbowl@163.com (L.W.); \\ jcmjc@163.com (M.J.); shihb@nbcdc.org.cn (H.S.) \\ 3 Ninghai Centers for Disease Prevention and Control, Ninghai 315600, China; hudanbiao@163.com \\ 4 Jiangdong District Centers for Disease Control and Prevention, Ningbo 315040, China; zljnb@126.com \\ 5 Zhenhai District Maternal and Child Health Family Planning Center, Ningbo 315200, China; \\ Fjian01@163.com \\ * Correspondence: zhaojinshun@nbu.edu.cn (J.Z.); 02maogc@163.com (G.M.); Tel.: +13515844181 (J.Z.) \\ + These authors contributed equally to this work.
}

Received: 17 January 2018; Accepted: 24 February 2018; Published: 28 February 2018

\begin{abstract}
Background: In order to search for effective control and prevention measures, the status of metal pollution in Ningbo, China was investigated. Methods: Nine of the most common contaminating metals including lead $(\mathrm{Pb})$, cadmium $(\mathrm{Cd})$, copper $(\mathrm{Cu})$, iron $(\mathrm{Fe})$, manganese $(\mathrm{Mn})$, chromium $(\mathrm{Cr})$, nickel $(\mathrm{Ni})$, zinc $(\mathrm{Zn})$, and mercury $(\mathrm{Hg})$ in samples of vegetables, rice, soil, irrigation water, and human hair were detected using inductively coupled plasma-mass spectrometry (ICP-MS). Three different districts including industrial, suburban and rural areas in Ningbo were studied through a stratified random sample method. Results: (1) Among all of the detected vegetable samples, Cd exceeded the standard limit rates in industrial, suburban and rural areas as high as $43.9 \%, 27.5 \%$ and $5.0 \%$, respectively; indicating the severity of Cd pollution in Ningbo. (2) The pollution index (PI) of $\mathrm{Cd}$ and $\mathrm{Zn}$ in soil $(1.069,1.584$, respectively) suggests that soil is slightly polluted by $\mathrm{Cd}$ and $\mathrm{Zn}$. Among all samples, metal contamination levels in soil were all relatively high. (3) A positive correlation was found between the concentrations of $\mathrm{Pb}, \mathrm{Cd}$ and $\mathrm{Cu}$ in vegetables and soil; $\mathrm{Pb}, \mathrm{Cu}$, $\mathrm{Cr}$ and $\mathrm{Ni}$ in vegetables and irrigation water, as well as, $\mathrm{Cu}$ and $\mathrm{Ni}$ in rice and irrigation water; and, (4) Higher $\mathrm{Pb}$ and $\mathrm{Cd}$ concentrations were found in student scalp hair in both industrial and suburban areas compared to rural areas. (5) $\mathrm{Hg}$ and $\mathrm{Pb}$ that are found in human scalp hair may be more easily absorbed from food than any of the other metals. Conclusions: In general, certain harmful metal pollutions were detected in both industrial and suburban areas of Ningbo in China.
\end{abstract}

Keywords: metal pollution; vegetable; rice; irrigation water; human hair

\section{Introduction}

Rapid industrialization in China has resulted in serious environmental pollution. Among the different types of pollutions, metal pollution is considered to be one of the major environmental issues [1]. Numerous applications of pesticides and fertilizers, industrial waste, mining, and smelting processing have drastically altered the balance and biogeochemical cycles of metals in the environment [2]. During the industrial processes, especially in the industrial and suburban areas, wastewater and solid waste may bring metals into the soil and water bodies [3]. Metals in the soil may 
then be transferred into crops or vegetables [4]. Metals in the water can also accumulate in the aquatic plants and aquatic animals [5,6]. Metals adhered to the industrial waste particles may suspend and travel in the air, and eventually enter the human body through different pathways $[7,8]$.

After entering the human body, it is difficult for metals to be completely metabolized. They may accumulate in soft tissues or in the bones, causing toxic effects [9-11]. In the human body, metals can insert adverse effects on cellular organelles and components, as well as enzymes involved in metabolism, detoxification, and DNA damage repair [12]. Recent studies show that lead can even result in a reduction in intelligence quotient (IQ) [13] and an increase of behavioral abnormities [14]. Mercury can accumulate in brain tissue and cause neurological dysfunction in humans and animals [15]. In addition, cadmium, hexavalent chromium and nickel compounds have been classified as human carcinogens by The International Agency for Research on Cancer (IARC). In the past decade, the concentration of metals in the soil of China was reported to be higher than normal and the detectable concentration of metals in certain foods was found to exceed the health standard limits [16] drawing great public attention and outcry [17]. As a major port city in China, Ningbo is known for the variety of aquatic products it offers. The health hazards of metal pollution through fish consumption have attracted wide attention in recent years [18]. As an important coastal economic district, Ningbo is one of the most industrialized cities in eastern China, however, few studies have been conducted to investigate the status of the metal pollution of this city. Exploring the pollution status of metals will be important for evaluating their potential health risks [19].

Therefore, the following objectives are included in the present study: (1) investigate the status of the nine most common contaminating metals, including lead $(\mathrm{Pb})$, cadmium $(\mathrm{Cd})$, copper $(\mathrm{Cu})$, iron $(\mathrm{Fe})$, manganese $(\mathrm{Mn})$, chromium $(\mathrm{Cr})$, nickel $(\mathrm{Ni})$, zinc $(\mathrm{Zn})$, and mercury $(\mathrm{Hg})$ from industrial, suburban and rural areas in Ningbo; (2) analyze the relationship between concentrations of selected metals in vegetables, rice, soil, irrigation water, and student scalp hair and search for an effective way to control and prevent these environmental pollutions; and, (3) provide some insights into metals accumulation in the agricultural ecosystem and human tissue to serve as a basis for comparison to other regions both in China and worldwide.

\section{Materials and Methods}

\subsection{Study Area and Sampling}

The Ningbo area is an important coastal industrial city which is located on a typical flat alluvial plain in the Yangtze River Delta region $\left(28^{\circ} 510^{\prime}-30^{\circ} 330^{\prime} \mathrm{N}, 120^{\circ} 550^{\prime}-122^{\circ} 160^{\prime}\right.$ E) [19]. Because of increased industrial development and rapid urban expansion in the past several decades, the soil environment is faced with metal contamination due to increasing pollutant inputs from anthropogenic sources. It is characterized as a subtropical mild and humid climate, a mean annual temperature of $16.4{ }^{\circ} \mathrm{C}$, and an annual precipitation of $1480 \mathrm{~mm}$. Due to rapid industrialization, metal pollution in paddy fields in the study area is of increasing concern. Moreover, the area is an important chemical industrial base in China. The textile and garment, chemical, and machinery industries are three main industrial pillars. Petrochemical, electronic, metallurgy, engineering, and building materials have also been developed [19]. In addition, Zhoushan Fisheries in Ningbo with rich fishing, has a large number of beach breeding base. The consumption of seafood may be one of sources of several kind of metals.

Three different districts including industrial, suburban and rural areas in Ningbo were studied by a stratified random sample method. The industrial and suburban areas were assumed to be possible severe contaminated areas, and the rural area was set as possibly none or a slightly contaminated area. The downtown area was not included in this study due to the uncertainty where the consumed vegetables or rice was produced, but the industrial and suburban areas are normally consumed from local produced vegetables and rice. One town or one street in each area was selected for sampling (where there was no electroplating, batteries, metal smelting, leather or other serious metal factories found within $0.5 \mathrm{~km}$ of the industrial area). Ten samples of greens, radish, cabbage, celery, and soil 
were collected from the farmlands located around the residential houses. The collected rice samples were produced in the local farmland, as well as, water samples used to irrigate these farmlands. Rice samples were not collected from suburban areas, because most residents in the suburban area purchase rice from other provinces or abroad. Hair samples were obtained from the local school students who had stayed in the sampling regions for more than five years. A total of 399 students (214 girls and 185 boys, 5-14 years old) were selected to participate in this study, (136 from rural areas, 161 from industrial areas, and the remaining 102 from suburban areas). All of the students were given an informed consent (written) for inclusion before they participated in the study. The study was conducted in accordance with the Declaration of Helsinki, and the protocol was approved by the Ethics Committee of the Ningbo University Ethics Committee (No. AEWC-2013-115) on 19 June 2013. Only the first $2.0 \mathrm{~cm}$ of hair proximal to the scalp was used for analysis [20].

\subsection{Metal Detection}

Soil samples (approximately $500 \mathrm{~g}$ ) were collected from the farmland surface (10-20 cm deep) and air-dried in the laboratory. Soil samples $(0.25 \mathrm{~g})$ were digested with a $6 \mathrm{~mL}$ acid mixture of 1:1:1 $\mathrm{HNO}_{3}-\mathrm{HCl}-\mathrm{HF}$ in a test tube [21]. The mixture was stirred and heated under reflux at $120^{\circ} \mathrm{C}$ for $1 \mathrm{~h}$, and then diluted to $50 \mathrm{~mL}$ with de-ionized water. Human hair samples were washed three times in de-ionized water and then dried on clean paper. Then, $0.5 \mathrm{~g}$ of hair sample was digested in a mixture of 5:1:2 $\mathrm{HNO}_{3}-\mathrm{H}_{2} \mathrm{O}_{2}-\mathrm{H}_{2} \mathrm{O}$ at $130{ }^{\circ} \mathrm{C}$ until no residue remained in the solution. The digested samples were cooled at room temperature and diluted to $25 \mathrm{~mL}$ with de-ionized distilled water for further analysis. Food samples were oven-dried at $105^{\circ} \mathrm{C}$ for $1 \mathrm{~h}$ and then at $70{ }^{\circ} \mathrm{C}$ until constant weight. Then, food samples were comminuted using a pulverizer and sieved through a nylon sieve with 100 meshes. Approximately $0.2 \mathrm{~g}$ food powder was digested by using $3 \mathrm{~mL} \mathrm{HNO}_{3}$ at $100 \pm 5{ }^{\circ} \mathrm{C}$ until no residue remained. All of the samples were treated and analyzed according to the national standard method GB/T5009-2003 [22]. All the samples were collected and treated fresh and detected by inductively coupled plasma-mass spectrometry (ICP-MS, Perkin-Elmer NexION 300D, PerkinElmer, Massachusetts, MA, USA) [22]. The accuracy of the determinations was verified using Chinese standardized reference materials: GBW10014 for GSB-5 cabbage, GBW10015 for GSB-6 green, GBW10010 for GSB-1 rice, GBW07424 for GSS-10 soil. The samples were measured in duplicate. For these procedures, reagent blanks were used in the analysis for quality assurance and quality control showed good precision throughout. The national hygienic standard for food and class II standard for soil in China is shown in Table 1. Chemical reagents used in this study were all ultrahigh purity [23].

Table 1. The national hygienic standard for food and class II standard for soil in China $(\mathrm{mg} / \mathrm{kg})$.

\begin{tabular}{ccccccccc}
\hline National Standard & Samples & $\mathbf{P b}$ & $\mathbf{C d}$ & $\mathbf{C u}$ & $\mathbf{C r}$ & $\mathbf{N i}$ & $\mathbf{Z n}$ & $\mathbf{H g}$ \\
\hline GB18406.1-2001 & vegetables & 0.2 & 0.05 & - & 0.5 & - & - & 0.01 \\
GB2762-2012 & rice & 0.2 & 0.2 & - & 1 & - & - & 0.02 \\
GB15618-1995* & soil & $\leq 300$ & $\leq 0.30$ & $\leq 100$ & $\leq 200$ & $\leq 50$ & $\leq 250$ & $\leq 0.50$ \\
GB5084-2005 & irrigation water & $\leq 0.20$ & $\leq 0.01$ & $\leq 1.00$ & $\leq 0.10$ & - & $\leq 2.00$ & $\leq 0.001$ \\
\hline \multicolumn{7}{c}{ Note: * Class II standard for soil in China. }
\end{tabular}

\subsection{Food Samples and Environmental Samples of Metal Pollution Assessment}

The food samples included 120 vegetable samples and 20 rice simples, the environmental samples included 30 soil samples and 30 irrigation water samples. The pollution levels of metals in food and environmental samples were evaluated using the pollution index (PI), (Equation (1)) [19];

$$
\mathrm{PI}=\frac{C_{i}}{S_{i}}
$$

where $C_{i}$ is the metal concentration of the sample, and $S_{i}$ is the pollution threshold of $i$, the equation applies for the chemical that was given the national hygienic standard. 
2.4. The Bioaccumulation Factor (BAF) of Food Samples, Environmental Samples and Student Hair Samples

The bioaccumulation factor (BAF) of each metal was used to assess the transfer of metals from food and environment to hair. It can be calculated as:

$$
\mathrm{BAF}_{1}=\frac{C_{h}}{C_{e}}
$$

where $C_{h}$ and $C_{e}$ are the total metal concentrations in hair samples and corresponding food and environmental samples, respectively [24].

\subsection{Statistical Analysis}

Statistical analysis was performed using SPSS V17.0 software (International Business Machines Corporation, Nork York, NY, USA) for Windows. Data of metal of food and environment are normal distribution, hair samples are log-normal distribution (One-Sample Kolmogorov-Smirnov Test), the median and percentile were used in hair samples data as statistics description. ANOVA Dunnett, $t$-test and correlation analysis were used. The statistical significance levels were set at $p<0.001, p<0.01$ and $p<0.05$.

\section{Results}

\subsection{Metal Detection in the Food Samples and Environmental Samples}

\subsubsection{In Food Samples (Vegetables and Rice)}

Table 2 shows the metal concentrations in different vegetables. The results indicate that average concentrations of $\mathrm{Cd}\left(q^{\prime}=0.038, p=0.01\right), \mathrm{Cu}\left(q^{\prime}=0.611, p=0.002\right), \mathrm{Cr}\left(q^{\prime}=0.046, p<0.001\right)$, and $\mathrm{Ni}\left(q^{\prime}=0.066, p=0.007\right)$ contained in four kinds of vegetables in the suburban area were significantly higher than that of the rural area; whereas, the average concentrations of $\mathrm{Pb}\left(q^{\prime}=0.031, p=0.027\right)$, $\mathrm{Cr}\left(q^{\prime}=0.039, p=0.002\right), \mathrm{Ni}\left(q^{\prime}=0.067, p=0.033\right)$, and $\mathrm{Hg}\left(q^{\prime}=0.005, p=0.013\right)$ in the industrial area were significantly higher than that of the rural area.

In the greens, the concentrations of $\mathrm{Cd}\left(q^{\prime}=0.016, p=0.017\right)$ and $\mathrm{Cr}\left(q^{\prime}=0.044, p=0.024\right)$ in the suburban area were significantly higher than that of the rural area.

In the radish, the concentrations of $\mathrm{Mn}\left(q^{\prime}=1.992, p=0.002\right)$ in the industrial area and $\mathrm{Cd}$ $\left(q^{\prime}=0.013, p=0.042\right)$ and $\mathrm{Cu}\left(q^{\prime}=0.328, p=0.012\right)$ in the suburban area were significantly higher than that of the rural area.

In the cabbage, only the concentration of $\mathrm{Hg}\left(q^{\prime}=0.001, p=0.045\right)$ in the industrial area was significantly higher than that of the rural area.

In the celery, the concentrations of $\mathrm{Pb}\left(q^{\prime}=0.074, p=0.046\right), \mathrm{Cu}\left(q^{\prime}=0.494, p=0.029\right)$ and $\mathrm{Cr}\left(q^{\prime}=0.055, p=0.006\right)$ in the industrial area and the concentrations of $\mathrm{Cu}\left(q^{\prime}=0.589, p=0.009\right)$ and $\mathrm{Cr}\left(q^{\prime}=0.055, p=0.006\right)$ in the suburban area were significantly higher than that of the rural area.

According to the GB18406.1-2001 standard [25], the level of Cd in the four vegetables that were studied in the suburban, industrial and rural area samples were $43.9 \%, 27.5 \%$, and $5.0 \%$, respectively exceeding the standard limit (data not shown).

Table 3 shows the metal concentrations in rice. The concentrations of $\mathrm{Cu}(t=5.078, p<0.001)$, $\mathrm{Cr}(t=2.419, p=0.030)$ and $\mathrm{Ni}(t=5.078, p<0.001)$ in the rice in the industrial area were significantly higher, whereas $\mathrm{Zn}(t=-5.728, p<0.001)$ was significantly lower, than that of the rural area. 
Table 2. Metal concentrations in different vegetables.

\begin{tabular}{|c|c|c|c|c|c|c|c|c|c|c|c|}
\hline \multirow{2}{*}{ Sample } & \multirow{2}{*}{ Area } & \multirow{2}{*}{$\mathbf{n}$} & \multicolumn{9}{|c|}{ Metal Concentrations (mg/kg, Means \pm SD) } \\
\hline & & & $\mathrm{Pb}$ & $\mathrm{Cd}$ & $\mathrm{Cu}$ & $\mathrm{Fe}$ & Mn & $\mathrm{Cr}$ & $\mathrm{Ni}$ & Zn & $\mathrm{Hg}$ \\
\hline \multirow{3}{*}{ Greens } & Rural & 10 & $0.031 \pm 0.009$ & $0.026 \pm 0.012$ & $0.372 \pm 0.114$ & $10.612 \pm 5.495$ & $6.851 \pm 6.647$ & $0.046 \pm 0.015$ & $0.092 \pm 0.038$ & $5.978 \pm 3.063$ & $0.0014 \pm 0.0007$ \\
\hline & Industrial & 10 & $0.053 \pm 0.058$ & $0.032 \pm 0.017$ & $0.577 \pm 0.242$ & $7.542 \pm 5.359$ & $9.039 \pm 8.666$ & $0.043 \pm 0.019$ & $0.278 \pm 0.332$ & $4.507 \pm 2.148$ & $0.0013 \pm 0.0006$ \\
\hline & Suburban & 10 & $0.062 \pm 0.077$ & $0.069 \pm 0.056^{*}$ & $1.579 \pm 2.491$ & $9.152 \pm 6.873$ & $5.043 \pm 3.344$ & $0.090 \pm 0.059 *$ & $0.375 \pm 0.709$ & $12.07 \pm 25.88$ & $0.0012 \pm 0.0007$ \\
\hline \multirow{3}{*}{ Radish } & Rural & 10 & $0.015 \pm 0.019$ & $0.006 \pm 0.004$ & $0.202 \pm 0.099$ & $3.353 \pm 3.772$ & $1.001 \pm 0.681$ & $0.031 \pm 0.010$ & $0.059 \pm 0.050$ & $2.623 \pm 1.498$ & $0.0007 \pm 0.0004$ \\
\hline & Industrial & 10 & $0.018 \pm 0.016$ & $0.013 \pm 0.007$ & $0.267 \pm 0.105$ & $3.109 \pm 2.878$ & $2.993 \pm 1.950 * *$ & $0.080 \pm 0.087$ & $0.161 \pm 0.177$ & $3.965 \pm 3.437$ & $0.0013 \pm 0.0013$ \\
\hline & Suburban & 10 & $0.020 \pm 0.020$ & $0.019 \pm 0.019$ * & $0.530 \pm 0.403 *$ & $2.461 \pm 1.878$ & $0.960 \pm 0.503$ & $0.068 \pm 0.049$ & $0.224 \pm 0.447$ & $3.189 \pm 5.932$ & $0.0004 \pm 0.0002$ \\
\hline \multirow{3}{*}{ Cabbage } & Rural & 10 & $0.040 \pm 0.039$ & $0.018 \pm 0.012$ & $0.254 \pm 0.074$ & $11.018 \pm 9.212$ & $11.379 \pm 17.602$ & $0.041 \pm 0.026$ & $0.067 \pm 0.029$ & $4.354 \pm 3.551$ & $0.0011 \pm 0.0005$ \\
\hline & Industrial & 10 & $0.067 \pm 0.057$ & $0.041 \pm 0.039$ & $0.479 \pm 0.273$ & $10.488 \pm 8.744$ & $8.297 \pm 7.892$ & $0.098 \pm 0.107$ & $0.261 \pm 0.216$ & $6.091 \pm 4.199$ & $0.0022 \pm 0.0014 *$ \\
\hline & Suburban & 10 & $0.072 \pm 0.079$ & $0.039 \pm 0.022$ & $0.504 \pm 0.337$ & $13.152 \pm 11.445$ & $2.511 \pm 1.203$ & $0.089 \pm 0.053$ & $0.208 \pm 0.280$ & $6.514 \pm 9.435$ & $0.0012 \pm 0.0008$ \\
\hline \multirow{3}{*}{ Celery } & Rural & 10 & $0.018 \pm 0.013$ & $0.034 \pm 0.017$ & $0.212 \pm 0.069$ & $8.182 \pm 6.689$ & $3.665 \pm 2.552$ & $0.034 \pm 0.013$ & $0.030 \pm 0.022$ & $2.850 \pm 1.340$ & $0.0011 \pm 0.0010$ \\
\hline & Industrial & 10 & $0.092 \pm 0.114 *$ & $0.091 \pm 0.118$ & $0.706 \pm 0.440 *$ & $11.752 \pm 9.377$ & $3.333 \pm 2.505$ & $0.089 \pm 0.033^{* *}$ & $0.192 \pm 0.192$ & $4.407 \pm 4.060$ & $0.0018 \pm 0.0015$ \\
\hline & Suburban & 10 & $0.037 \pm 0.038$ & $0.109 \pm 0.136$ & $0.801 \pm 0.591 * *$ & $7.578 \pm 3.988$ & $2.186 \pm 1.063$ & $0.089 \pm 0.055^{* *}$ & $0.225 \pm 0.261$ & $3.881 \pm 2.556$ & $0.0007 \pm 0.0002$ \\
\hline \multirow{3}{*}{$\begin{array}{c}\text { Four } \\
\text { Vegetables }\end{array}$} & Rural & 40 & $0.026 \pm 0.024$ & $0.021 \pm 0.016$ & $0.260 \pm 0.111$ & $8.291 \pm 7.050$ & $5.724 \pm 9.932$ & $0.038 \pm 0.017$ & $0.062 \pm 0.041$ & $3.951 \pm 2.805$ & $0.0011 \pm 0.0007$ \\
\hline & Industrial & 40 & $0.057 \pm 0.073^{*}$ & $0.044 \pm 0.067$ & $0.507 \pm 0.323$ & $8.223 \pm 7.603$ & $5.916 \pm 6.472$ & $0.077 \pm 0.072 * *$ & $0.223 \pm 0.233 *$ & $4.742 \pm 3.511$ & $0.0016 \pm 0.0013 *$ \\
\hline & Suburban & 40 & $0.048 \pm 0.061$ & $0.059 \pm 0.079 *$ & $0.871 \pm 1.376^{* * *}$ & $8.112 \pm 7.769$ & $2.733 \pm 2.403$ & $0.084 \pm 0.053^{* * *}$ & $0.261 \pm 0.457^{* *}$ & $6.551 \pm 14.486$ & $0.0009 \pm 0.0006$ \\
\hline
\end{tabular}

Note: ${ }^{* * *} p<0.001,{ }^{* *} p<0.01,{ }^{*} p<0.05$. Dunnett test, versus rural.

Table 3. Metal concentrations in rice.

\begin{tabular}{|c|c|c|c|c|c|c|c|c|c|c|c|}
\hline \multirow{2}{*}{$\begin{array}{c}\text { Sample } \\
\text { Name }\end{array}$} & \multirow{2}{*}{ Area } & \multirow{2}{*}{$\mathbf{n}$} & \multicolumn{9}{|c|}{ Metal Concentrations (mg/kg, Means \pm SD) } \\
\hline & & & $\mathrm{Pb}$ & $\mathrm{Cd}$ & $\mathrm{Cu}$ & $\mathrm{Fe}$ & Mn & $\mathrm{Cr}$ & $\mathrm{Ni}$ & $\mathrm{Zn}$ & $\mathrm{Hg}$ \\
\hline \multirow[b]{2}{*}{ Rice } & Rural & 10 & $0.027 \pm 0.034$ & $0.071 \pm 0.061$ & $2.147 \pm 0.737$ & $12.46 \pm 19.227$ & $11.938 \pm 4.33$ & $0.072 \pm 0.044$ & $0.154 \pm 0.082$ & $15.899 \pm 2.581$ & $0.0017 \pm 0.0012$ \\
\hline & Industrial & 10 & $0.004 \pm 0.000$ & $0.132 \pm 0.043$ & $8.002 \pm 2.530 * * *$ & $1.471 \pm 0.418$ & $8.704 \pm 2.757$ & $0.128 \pm 0.042 *$ & $0.519 \pm 0.086^{* * *}$ & $8.115 \pm 2.359^{* * *}$ & $0.0018 \pm 0.0004$ \\
\hline
\end{tabular}

Note: ${ }^{* * *} p<0.001, * p<0.05 . t$-test, versus rural. 


\subsubsection{In the Environmental Samples (Soil and Irrigation Water)}

Table 4 shows the metal concentrations in soil. The mean concentrations of $\mathrm{Pb}, \mathrm{Cd}, \mathrm{Cu}, \mathrm{Fe}, \mathrm{Mn}, \mathrm{Cr}$, $\mathrm{Ni}, \mathrm{Zn}$ and $\mathrm{Hg}$ in soils are 50.06, 0.29, 53.39, 32,231.12, 733.46, 81.91, 39.53, 396.04, 0.11, and $11.46 \mathrm{mg} / \mathrm{kg}$, respectively. The total $\mathrm{Cd}$ in Ningbo area were $32.25 \%$ exceeding the standard limit exceed their class II standard. The Hg concentrations in both suburban $\left(q^{\prime}=0.110, p=0.016\right)$ and industrial $\left(q^{\prime}=0.104\right.$, $p=0.020$ ) areas were significantly higher than that of the rural areas.

Table 5 shows the metal concentrations in irrigation water. Differences in $\mathrm{Cd}, \mathrm{Cu}$, and $\mathrm{Mn}$ concentrations in the irrigation water were observed among three areas. In irrigation water, $\mathrm{Cd}$ $\left(q^{\prime}=0.053, p=0.041\right)$ and $\mathrm{Mn}\left(q^{\prime}=251.222, p<0.001\right)$ in the industrial area and $\mathrm{Cu}\left(q^{\prime}=6.37, p=0.04\right)$ and $\operatorname{Mn}\left(q^{\prime}=125.162, p=0.005\right)$ in the suburban areas were significantly higher than that in the rural areas.

\subsubsection{Assessment of Metal Pollution in Food and Environment}

The descriptive statistics of the pollution index (PI) of metal concentrations in food and the environment is presented in Table 6. The PI of each of the metals was calculated to assess the pollution degree of different metals in food and the environment, it was classified according to five classes: $\mathrm{PI} \leq 1.0$ (safe), $1.0<\mathrm{PI} \leq 2.0$ (slight pollution), $2.0<\mathrm{PI} \leq 3.0$ (mild pollution), $3.0<\mathrm{PI} \leq 5.0$ (moderate pollution), and PI $>5.0$ (severe pollution). The PIs of all the elements were at the safe level, except $\mathrm{Cd}$ and $\mathrm{Zn}$ in soil $(1.069,1.584)$, which means that the soil is slightly polluted. In addition, according to the PI, Cd contamination levels in vegetables, rice, and soil were relatively high. Among all of the samples, soil contamination levels were relatively high. The PIs of soil were in the following decreasing order: $\mathrm{Zn}(1.584)>\mathrm{Cd}(1.069)>\mathrm{Ni}(0.791)>\mathrm{Cu}(0.534)>\mathrm{Cr}(0.410)>\mathrm{Pb}(0.167)$.

\subsubsection{Correlation Analysis of Metals between Environmental Samples and Food Samples}

Table 7 shows the correlation analysis of metal concentrations in different environmental samples. A positive correlation was found between the concentrations of $\mathrm{Pb}(r=0.793, p<0.01), \mathrm{Cd}(r=0.745$, $p<0.01)$ and $\mathrm{Cu}(r=0.604, p<0.05)$ in vegetables and soil. $\mathrm{Pb}(r=0.648, p<0.05), \mathrm{Cu}(r=0.967$, $p<0.001), \mathrm{Cr}(r=0.587, p<0.05)$, and $\mathrm{Ni}(r=0.804, p<0.001)$ in vegetables were correlated with that in irrigation water. $\mathrm{Cu}(r=0.885, p<0.001)$ and $\mathrm{Ni}(r=0.796, p<0.01)$ in rice were correlated with that in irrigation water. 
Table 4. Metal concentrations in soil.

\begin{tabular}{|c|c|c|c|c|c|c|c|c|c|c|c|}
\hline \multirow{2}{*}{$\begin{array}{l}\text { Sample } \\
\text { Name }\end{array}$} & \multirow{2}{*}{ Area } & \multirow{2}{*}{$\mathbf{n}$} & \multicolumn{9}{|c|}{ Metal Concentrations $(\mathrm{mg} / \mathrm{kg}$, Means $\pm \mathrm{SD})$} \\
\hline & & & $\mathrm{Pb}$ & Cd & $\mathrm{Cu}$ & $\mathrm{Fe}$ & Mn & $\mathrm{Cr}$ & $\mathrm{Ni}$ & $\mathrm{Zn}$ & $\mathrm{Hg}$ \\
\hline \multirow{3}{*}{ Soil } & Rural & 10 & $34.56 \pm 6.42$ & $0.22 \pm 0.08$ & $31.6 \pm 19.02$ & $30,077.0 \pm 27,551.0$ & $604.0 \pm 255.0$ & $59.7 \pm 55.5$ & $34.86 \pm 40.06$ & $393.5 \pm 558.5$ & $0.03 \pm 0.03$ \\
\hline & Industrial & 10 & $57.32 \pm 34.10$ & $0.24 \pm 0.09$ & $47.73 \pm 14.59$ & $31,225.8 \pm 13,781.5$ & $992.0 \pm 1071.0$ & $100.0 \pm 29.5$ & $46.34 \pm 10.57$ & $582.9 \pm 622.2$ & $0.14 \pm 0.08$ \\
\hline & Suburban & 10 & $57.56 \pm 28.58$ & $0.49 \pm 0.51$ & $78.34 \pm 94.18$ & $35,103.3 \pm 7764.2$ & $616.1 \pm 204.3$ & $85.6 \pm 34.4$ & $37.59 \pm 12.17$ & $228.4 \pm 166.0$ & $0.14 \pm 0.12$ \\
\hline
\end{tabular}

Table 5. Metal concentrations in irrigation water.

\begin{tabular}{|c|c|c|c|c|c|c|c|c|c|c|c|}
\hline \multirow{2}{*}{$\begin{array}{l}\text { Sample } \\
\text { Name }\end{array}$} & \multirow{2}{*}{ Area } & \multirow{2}{*}{$\mathbf{n}$} & \multicolumn{9}{|c|}{ Metal Concentrations ( $\mu \mathrm{g} / \mathrm{L}$, Means $\pm \mathrm{SD}$ ) } \\
\hline & & & $\mathrm{Pb}$ & $\mathrm{Cd}$ & $\mathrm{Cu}$ & $\mathrm{Fe}$ & Mn & $\mathrm{Cr}$ & $\mathrm{Ni}$ & Zn & $\mathrm{Hg}$ \\
\hline \multirow{3}{*}{$\begin{array}{l}\text { Irrigation } \\
\text { Water }\end{array}$} & Rural & 10 & $0.56 \pm 0.83$ & $0.04 \pm 0.02$ & $0.72 \pm 0.29$ & $152.34 \pm 112.44$ & $10.37 \pm 11.97$ & $0.62 \pm 0.22$ & $0.55 \pm 0.23$ & $64.13 \pm 191.82$ & $0.03 \pm 0.02$ \\
\hline & Industrial & 10 & $1.70 \pm 2.16$ & $0.09 \pm 0.08 *$ & $3.99 \pm 1.73$ & $190.53 \pm 73.04$ & $261.59 \pm 136.40^{* * *}$ & $3.09 \pm 4.36$ & $10.84 \pm 17.73$ & $52.89 \pm 67.19$ & $0.04 \pm 0.01$ \\
\hline & Suburban & 10 & $1.52 \pm 0.72$ & $0.05 \pm 0.01$ & $7.46 \pm 10.55 *$ & $212.67 \pm 69.46$ & $135.53 \pm 55.73^{* * *}$ & $2.04 \pm 0.93$ & $4.21 \pm 2.63$ & $21.93 \pm 16.32$ & $0.06 \pm 0.05$ \\
\hline
\end{tabular}


Table 6. Descriptive statistics of PIs metal concentrations in food and the environment.

\begin{tabular}{cccccccc}
\hline Samples & $\mathbf{P b}$ & $\mathbf{C d}$ & $\mathbf{C u}$ & $\mathbf{C r}$ & $\mathbf{N i}$ & $\mathbf{Z n}$ & $\mathbf{H g}$ \\
\hline Vegetables & 0.220 & 0.832 & - & 0.133 & - & - & 0.012 \\
Rice & 0.100 & 0.450 & - & 0.089 & - & - & 0.087 \\
Soil & 0.167 & 1.069 & 0.534 & 0.410 & 0.791 & 1.584 & 0.215 \\
Irrigation Water & 0.006 & 0.006 & 0.004 & 0.019 & - & 0.023 & 0.042 \\
\hline
\end{tabular}

Table 7. Correlation analysis of metal concentrations among different environmental samples.

\begin{tabular}{cccc}
\hline & & Vegetables & Rice \\
\hline \multirow{2}{*}{$\mathrm{Pb}$} & soils & $0.793^{* *}$ & -0.382 \\
& Irrigation water & $0.648^{*}$ & -0.064 \\
\hline \multirow{2}{*}{$\mathrm{Cd}$} & soils & $0.745^{* *}$ & 0.152 \\
& Irrigation water & 0.442 & 0.023 \\
\hline \multirow{2}{*}{$\mathrm{Cu}$} & soils & $0.604^{*}$ & 0.484 \\
& Irrigation water & $0.967^{* * *}$ & $0.885^{* * *}$ \\
$\mathrm{~F} \mathrm{Fe}$ & soils & -0.335 & -0.087 \\
& Irrigation water & 0.225 & -0.206 \\
\hline \multirow{2}{*}{$\mathrm{Mn}$} & soils & -0.218 & 0.376 \\
& Irrigation water & -0.079 & -0.246 \\
\hline \multirow{2}{*}{$\mathrm{Cr}$} & soil & 0.339 & -0.135 \\
& Irrigation water & $0.587^{*}$ & 0.279 \\
\hline \multirow{2}{*}{$\mathrm{Ni}$} & soils & 0.295 & 0.169 \\
& Irrigation water & $0.804^{* * *}$ & $0.796 *$ \\
\hline \multirow{2}{*}{$\mathrm{Zn}$} & soils & 0.382 & -0.555 \\
& Irrigation water & -0.112 & -0.026 \\
\hline \multirow{2}{*}{$\mathrm{Hg}$} & soils & -0.088 & -0.151 \\
& Irrigation water & 0.525 & 0.530 \\
\hline
\end{tabular}

Note: ${ }^{* *} p<0.001,{ }^{* *} p<0.01,{ }^{*} p<0.05$, correlation analysis.

\subsection{Metal Detection in Student Scalp Hair Samples}

\subsubsection{Metal Concentrations in Student Scalp Hair Samples}

Table 8 shows the metal concentrations in student hair. Hair samples are log-normal distribution (One-Sample Kolmogorov-Smirnov Test), the median and percentile were used in hair samples data as statistics description. There was a striking difference in the concentration of different metals: the concentrations for $\mathrm{Pb}, \mathrm{Cd}, \mathrm{Cu}, \mathrm{Fe}, \mathrm{Mn}, \mathrm{Cr}, \mathrm{Ni}, \mathrm{Zn}$, and $\mathrm{Hg}$ were 4.581, 0.096, 7.532, 21.025, 3.134, 0.127, $0.313,240.978$, and $0.242 \mathrm{mg} / \mathrm{kg}$. The median concentrations of $\mathrm{Pb}, \mathrm{Cd}$, and $\mathrm{Hg}$ in human hair were all within the reference concentration range reported previously [26]. After pairwise comparison between the two areas, metal concentrations in scalp hair of students were in the following order: for $\mathrm{Pb}$ : (industrial and suburban areas) > rural areas, for $\mathrm{Cd}$ : suburban areas $>$ industrial areas $>$ rural areas, for $\mathrm{Cu}$ : (rural areas $>$ suburban areas) > industrial areas, for Fe: suburban areas $>$ industrial areas > rural areas, for Mn: (rural, industrial areas) > suburban areas, for Cr (suburban, rural areas) > industrial areas, for Ni: rural areas $>$ (industrial and suburban areas), for Zn: industrial areas $>$ rural areas > suburban areas, for Hg: (rural areas > suburban areas) > industrial areas. After transformed into log-normal distribution of hair metals, ANOVA, Dunnett and correlation analysis were used (Table 8). Compared to rural areas, the concentrations of $\mathrm{Pb}\left(q^{\prime}=0.296, p<0.001\right), \mathrm{Cd}\left(q^{\prime}=0.154\right.$, $p<0.001), \mathrm{Fe}\left(q^{\prime}=0.662, p<0.001\right)$, and $\mathrm{Zn}\left(q^{\prime}=0.140, p<0.001\right)$ in student hair in industrial areas and the concentrations of $\mathrm{Pb}\left(q^{\prime}=0.366, p<0.001\right), \mathrm{Cd}\left(q^{\prime}=0.333, p<0.001\right)$ and $\mathrm{Fe}\left(q^{\prime}=0.799, p<0.001\right)$ in student hair in suburban areas were all significantly high. When compared to rural areas, the 
concentrations of $\mathrm{Cu}\left(q^{\prime}=0.081, p=0.001\right), \mathrm{Cr}\left(q^{\prime}=0.189, p<0.001\right), \mathrm{Ni}\left(q^{\prime}=0.326, p<0.001\right)$, and $\mathrm{Hg}\left(q^{\prime}=0.134, p<0.001\right)$ in student hair in industrial areas and the concentrations of $\operatorname{Mn}\left(q^{\prime}=0.144\right.$, $p=0.001), \mathrm{Ni}\left(q^{\prime}=0.340, p<0.001\right)$, and $\mathrm{Zn}\left(q^{\prime}=0.267, p<0.001\right)$ in student hair in suburban areas were all significantly low. Furthermore, in order to investigate the correlation between the studied metal concentrations recorded in the scalp hair, the Pearson's correlation coefficient was calculated and is shown in Table 9. The correlation analysis showed that the six metals $(\mathrm{Pb}, \mathrm{Cd}, \mathrm{Cu}, \mathrm{Mn}, \mathrm{Cr}$ and $\mathrm{Ni}$ ) in the hair of the students were positively correlated with each other. In addition, Fe was positively correlated with $\mathrm{Pb}, \mathrm{Cd}, \mathrm{Cu}, \mathrm{Mn}$, and $\mathrm{Cr}$, and there was a positive correlation between $\mathrm{Zn}$ and $\mathrm{Cu}, \mathrm{Mn}$ and $\mathrm{Ni}, \mathrm{Hg}$, and $\mathrm{Cu}, \mathrm{Cr}, \mathrm{Ni}$.

Table 8. Metal concentrations in student scalp hair in the rural, industrial and suburban areas.

\begin{tabular}{|c|c|c|c|c|c|c|c|c|c|c|}
\hline \multirow{2}{*}{ Area } & \multirow{2}{*}{$\mathbf{n}$} & \multicolumn{9}{|c|}{ Metal Concentrations (mg/kg, Median (Q25, Q75)) } \\
\hline & & $\mathbf{P b}$ & Cd & $\mathrm{Cu}$ & $\mathrm{Fe}$ & Mn & $\mathrm{Cr}$ & $\mathrm{Ni}$ & $\mathrm{Zn}$ & $\mathrm{Hg}$ \\
\hline Rural & 136 & $\begin{array}{c}2.99 \\
(1.87,4.48)\end{array}$ & $\begin{array}{c}0.07 \\
(0.05,0.10)\end{array}$ & $\begin{array}{c}8.46 \\
(7.00,10.91)\end{array}$ & $\begin{array}{c}5.38 \\
(4.50,7.31)\end{array}$ & $\begin{array}{c}3.64 \\
(2.29,5.67)\end{array}$ & $\begin{array}{c}0.15 \\
(0.10,0.22)\end{array}$ & $\begin{array}{c}0.63 \\
(0.36,1.01)\end{array}$ & $\begin{array}{c}250.25 \\
(185.60,376.08)\end{array}$ & $\begin{array}{c}0.26 \\
(0.20,0.33)\end{array}$ \\
\hline Industrial & 161 & $\begin{array}{c}5.38 \text { *** } \\
(3.33,9.67)\end{array}$ & $\begin{array}{c}0.10 * * * \\
(0.06,0.16)\end{array}$ & $\begin{array}{c}6.67^{* * *} \\
(5.73,9.13)\end{array}$ & $\begin{array}{c}24.67^{* * *} \\
(19.87,35.32)\end{array}$ & $\begin{array}{c}3.05 \\
(1.95,5.50)\end{array}$ & $\begin{array}{c}0.10^{* * *} \\
(0.06,0.15)\end{array}$ & $\begin{array}{c}0.27^{* * *} \\
(0.15,0.45)\end{array}$ & $\begin{array}{c}331.41^{* * *} \\
(225.15,578.85)\end{array}$ & $\begin{array}{c}0.20 * * * \\
(0.13,0.28)\end{array}$ \\
\hline Suburban & 102 & $\begin{array}{c}7.38^{* * * *} \\
(4.18,11.91)\end{array}$ & $\begin{array}{c}0.14^{* * *} \\
(0.10,0.21)\end{array}$ & $\begin{array}{c}7.74 \\
(6.36,10.67)\end{array}$ & $\begin{array}{c}34.31^{* * *} \\
(26.60,47.38)\end{array}$ & $\begin{array}{c}2.81^{* * *} \\
(1.71,4.34)\end{array}$ & $\begin{array}{c}0.16 \\
(0.11,0.23)\end{array}$ & $\begin{array}{c}0.22 * * * \\
(0.15,0.37)\end{array}$ & $\begin{array}{c}145.85^{* * *} \\
(112.32,179.60)\end{array}$ & $\begin{array}{c}0.29 \\
(0.17,0.47)\end{array}$ \\
\hline $\begin{array}{c}\text { Total } \\
\text { median }\end{array}$ & 399 & $\begin{array}{c}4.58 \\
(2.73,7.95)\end{array}$ & $\begin{array}{c}0.010 \\
(0.06,0.16)\end{array}$ & $\begin{array}{c}7.53 \\
(6.21,10.29)\end{array}$ & $\begin{array}{c}21.03 \\
(6.91,33.48)\end{array}$ & $\begin{array}{c}3.13 \\
(1.94,5.27)\end{array}$ & $\begin{array}{c}0.13 \\
(0.09,0.20)\end{array}$ & $\begin{array}{c}0.31 \\
(0.18,0.71)\end{array}$ & $\begin{array}{c}240.98 \\
(170.46,400.10)\end{array}$ & $\begin{array}{c}0.24 \\
(0.16,0.33)\end{array}$ \\
\hline $\begin{array}{l}\text { Published } \\
\text { Range [26] }\end{array}$ & & $0.004-95$ & $0.02-16$ & - & - & - & $0.03-16$ & - & - & $0.07-106$ \\
\hline
\end{tabular}

Note: Note: ${ }^{* * *} p<0.001$. ANOVA, Dunnett, after transformed into log-normal distribution of hair metals.

Table 9. Correlation analysis of nine metals in the hair of students.

\begin{tabular}{cccccccccc}
\hline & $\mathbf{P b}$ & $\mathbf{C d}$ & $\mathbf{C u}$ & $\mathbf{F e}$ & $\mathbf{M n}$ & $\mathbf{C r}$ & $\mathbf{N i}$ & $\mathrm{Zn}$ & $\mathbf{H g}$ \\
\hline $\mathrm{Pb}$ & - & & & & & & & & \\
$\mathrm{Cd}$ & $0.660^{* * *}$ & - & & & & & & \\
$\mathrm{Cu}$ & $0.346^{* * *}$ & $0.366^{* * *}$ & - & & & & & \\
$\mathrm{Fe}$ & $0.555^{* * *}$ & $0.478^{* * *}$ & $0.136^{* *}$ & - & & & & \\
$\mathrm{Mn}$ & $0.470^{* * *}$ & $0.435^{* * *}$ & $0.410^{* * *}$ & $0.163^{* *}$ & - & & & \\
$\mathrm{Cr}$ & $0.253^{* * *}$ & $0.262^{* * *}$ & $0.322^{* * *}$ & $0.103^{*}$ & $0.318^{* * *}$ & - & & \\
$\mathrm{Ni}$ & $0.195^{* * *}$ & $0.180^{* * *}$ & $0.523^{* * *}$ & -0.082 & $0.533^{* * *}$ & $0.336^{* * *}$ & - & \\
$\mathrm{Zn}$ & 0.095 & 0.010 & $0.221^{* * *}$ & -0.026 & $0.272^{* * *}$ & 0.007 & $0.384^{* * *}$ & - \\
$\mathrm{Hg}$ & -0.010 & -0.022 & $0.163^{* *}$ & -0.053 & -0.039 & $0.121^{*}$ & $0.117^{*}$ & $-0.105^{*}$ & - \\
\hline
\end{tabular}

Note: ${ }^{* * *} p<0.001,{ }^{* *} p<0.01,{ }^{*} p<0.05$, correlation analysis.

\subsubsection{The Bioaccumulation Factor (BAF) of Metals in the Hair, Food and Environmental Samples}

The bioaccumulation factor (BAF) of metals in the hair, food, and environmental samples is shown in Table 10. The largest BAF of hair from students consuming vegetables was for $\mathrm{Hg}$ (201.3) and $\mathrm{Pb}$ (104.2) and the largest BAF of hair from students consuming rice was for $\mathrm{Pb}$ (299.7) and $\mathrm{Hg}$ (138.6), which indicates that hair may absorb $\mathrm{Hg}$ and $\mathrm{Pb}$ more easily from food than any of the other metals. While the smallest BAFs of hair from students consuming vegetables and rice were for $\mathrm{Mn}(0.7$ and 0.3 , respectively), in addition, Mn was identified as having the lowest accumulation in all of the hair samples studied. Soil had the largest BAF for $\mathrm{Hg}$ (4.033) and the smallest for $\mathrm{Fe}$ and $\mathrm{Cr}(0.001$ and 0.001). Irrigation water had the largest BAF for $\mathrm{Zn}$ (5203) and the smallest for $\mathrm{Mn}$ (23), indicating that $\mathrm{Hg}$ and $\mathrm{Zn}$ were more easily absorbed by the hair via the environment-food-human system, while Fe, $\mathrm{Cr}$, and $\mathrm{Mn}$ were the least absorbed by the hair via this system. 
Table 10. Bioaccumulation factor (BAF) of metals between student's hair, food and environmental samples.

\begin{tabular}{cccccccccc}
\hline Ratio & $\mathbf{P b}$ & $\mathbf{C d}$ & $\mathbf{C u}$ & $\mathbf{F e}$ & $\mathbf{M n}$ & $\mathbf{C r}$ & $\mathbf{N i}$ & $\mathbf{Z n}$ & $\mathbf{H g}$ \\
\hline hair/vegetables & 104.2 & 2.3 & 13.7 & 2.6 & 0.7 & 1.9 & 1.7 & 47.3 & 201.3 \\
hair/rice & 229.7 & 1.1 & 1.9 & 2.3 & 0.3 & 1.4 & 1.2 & 17.9 & 138.6 \\
hair/soil & 0.148 & 0.533 & 0.217 & 0.001 & 0.004 & 0.001 & 0.006 & 1.865 & 4.033 \\
hair/irrigation & 3636 & 1655 & 1856 & 114 & 23 & 66 & 60 & 5203 & 5717 \\
\hline
\end{tabular}

\section{Discussion}

In this study, we found that the average concentrations of $\mathrm{Cd}, \mathrm{Cu}, \mathrm{Cr}$, and $\mathrm{Ni}$ in four evaluated vegetables in the suburban area of Ningbo, China were significantly higher than in the rural area. However, in the industrial area, the average concentrations of $\mathrm{Pb}, \mathrm{Cr}, \mathrm{Ni}$, and $\mathrm{Hg}$ were significantly higher than the rural area. The amount of $\mathrm{Cd}$ in the four evaluated vegetables in suburban, industrial and rural area samples reached $43.9 \%, 27.5 \%$, and $5.0 \%$, respectively, exceeding the standard limit. Rice produced in the industrial area had more $\mathrm{Cu}, \mathrm{Cr}$, and $\mathrm{Ni}$ contamination than that of the rural area. These results indicate that metal pollution in the suburban and industrial areas were more serious than in the rural area, especially $\mathrm{Cd}$ pollution, due to the dramatically increased industrial operations and rapid urban expansion in the past three decades in Ningbo. In addition, the relatively high PI of Cd in vegetables also indicated $\mathrm{Cd}$ contamination. The dynamic uptake of metals varies at different growth points for different vegetables [27]. Our results also show that the accumulations of different metals in different vegetables or rice are different.

In soil samples, we found only the $\mathrm{Hg}$ concentrations in both suburban and industrial areas were significantly higher than in the rural area [28]. $\mathrm{Pb}, \mathrm{Cd}, \mathrm{Cu}, \mathrm{Fe}, \mathrm{Mn}, \mathrm{Cr}$, and Ni concentrations in the industrial and suburban soil samples were also higher than that of the rural samples although no significant difference was found. The soil environment is faced with metal contamination due to increasing pollutant inputs from anthropogenic sources. In irrigation water, $\mathrm{Cd}$ and $\mathrm{Mn}$ in the industrial area and $\mathrm{Cu}$ and $\mathrm{Mn}$ in the suburban area were significantly higher than in the rural area. The pollution index (PI) suggests that soil is slightly polluted with $\mathrm{Cd}$ and $\mathrm{Zn}$. In addition, according to the PI, Cd contamination levels in vegetables, rice, and soil were relatively high. After analyzing the relationship of metal concentrations among different environmental and food samples, we found that the concentrations of $\mathrm{Pb}, \mathrm{Cd}$, and $\mathrm{Cu}$ in vegetables were positively correlated with that of the soil. $\mathrm{Pb}, \mathrm{Cu}, \mathrm{Cr}$ and $\mathrm{Ni}$ in vegetables were positively correlated with that in irrigation water. In addition, $\mathrm{Cu}$ and $\mathrm{Ni}$ in rice were positively correlated with that in irrigation water. These results indicate that metal contaminations in different vegetables or rice may be the result of soil and irrigation water pollution [29]. Previous studies show that vegetables and crops may take up metals when grown in polluted soil and long-term accumulation of metals in soil can consequently cause an increase in metal uptake by vegetables [30,31].

Our results are in agreement with the conclusion of Briki et al. a higher level of metal contaminations exists in suburban and industrial areas than that of rural areas [32], except for Zn. Interestingly, in this study, we found that Zn concentrations in rice, irrigation water, and human hair in the suburban and industrial areas were all significantly lower than that of the rural areas. The reason for this phenomenon is not clear. It may be caused by the imbalance of different metals in the environment.

The biological monitoring of metal pollution for human exposure is of optimal interest for researchers [33]. As a stable matrix for human bio-monitoring [34], human hair has many advantages, such as easy collection, low cost, easy transport and storage [35], and less invasive [36]. Monitoring of minor or trace elements in human hair has become an effective method for toxic trace metal exposure in recent years $[37,38]$. Young students are more vulnerable to metal hazards than other age groups and can reflect the environmental influence sensitivity $[39,40]$. 
In our study, though median concentrations of $\mathrm{Pb}, \mathrm{Cd}$, and $\mathrm{Hg}$ in student hair were all within the reference concentration range reported previously, the concentrations of $\mathrm{Pb}, \mathrm{Cd}$ in industrial and suburban areas were all significantly higher than rural areas. The bioaccumulation factor (BAF) of $\mathrm{Pb}$ and $\mathrm{Hg}$ in the hair samples from vegetables, rice was relatively high, reflecting that metals accumulated in the students' bodies mainly originated from food. Soil had the largest BAF for $\mathrm{Hg}$, indicating that $\mathrm{Hg}$ were more easily absorbed by the hair via the environment-food-human system. Eliminating metals in the environment is the basic method to reduce metal levels in the hair. The correlation analysis showed that the six metals $(\mathrm{Pb}, \mathrm{Cd}, \mathrm{Cu}, \mathrm{Mn}, \mathrm{Cr}$, and $\mathrm{Ni})$ in the hair of the students were positively correlated with each other. It can be seen from a correlation among various trace metals that there exists a mutual dependence of these metals in the environment, which is probably due to their similar chemical nature [31]. Many of these associations are difficult to explain with the information available and further studies are required for a better understanding of correlations between different metals.

$\mathrm{Pb}, \mathrm{Cd}$, and $\mathrm{Hg}$ are nonessential elements, which are widely distributed at low levels in the environment [41], In this study, we found that the average concentrations of $\mathrm{Pb}$ and $\mathrm{Cd}$ in student hair, including both industrial and suburban areas, were significantly higher than that of rural areas and the $\mathrm{Hg}$ concentrations in both suburban and industrial areas were significantly higher than in the rural areas. These results suggest that adverse health effects of harmful metal pollution in the industrial and suburban areas in Ningbo, China should not be neglected [42].

Further studies should focus on the following issues:

(1) More studies concerning the relationship between metals concentrations in human tissue and food should be conducted. (2) More reference of metals in body tissue should be studied and updated frequently, especially for children. (3) Every element in the food chain should be used to investigate the dynamic uptake of metals.

\section{Conclusions}

In general, we found that metal pollution in the suburban and industrial areas was more serious than that in the rural areas; among all the detected vegetable samples, $\mathrm{Cd}$ rates exceeds the standard limit and is higher in the industrial and suburban areas when compared to the rural areas. Thus, $\mathrm{Cd}$ pollution in Ningbo is a serious one; Higher $\mathrm{Pb}$ and $\mathrm{Cd}$ concentrations were found in student hair in both industrial and suburban areas compared to rural areas. In conclusion, certain harmful metal pollutions were detected in both industrial and suburban areas of Ningbo in China.

Acknowledgments: The authors would like to thank Linda Bowman for her assistance in the preparation of this article. This study was partly supported by the National Nature Science Foundation of China (grant no. 81273111), Scientific Projects of Zhejiang Province (grant nos. 2015C33148 and 2015C37117), the Ningbo Scientific Innovation Team for Environmental Hazardous Factor Control and Prevention (grant no. 2016C51001), Zhejiang Key Laboratory of Pathophysiology (201703), and the KC Wong Magna Fund of Ningbo University.

Author Contributions: Jinshun Zhao, Guochuan Mao and Zhou Li conceived and designed the experiments. Guochuan Mao, Samuel Selorm Fiati Kenston, Xin Song performed the experiments. Zhou Li, Hong Su, Li Wang and Danbiao Hu analyzed the data. Lijun Zhang and Jian Fang contributed materials and analysis tools. Zhou Li and Hongbo Shi drafted the work. Guochuan Mao, Jinshun Zhao and Micong Jin assisted the preparation of this article and substantially revised it. All authors read and approved the final manuscript. In addition, all authors have approved the submitted version and agree to be personally accountable for the author's own contributions.

Conflicts of Interest: The authors declare no conflict of interest.

\section{References}

1. Hu, H.; Jin, Q.; Kavan, P. A study of heavy metal pollution in China: Current status, pollution-control policies and countermeasures. Sustainability 2014, 6, 5820-5838. [CrossRef]

2. Shisia, K.S. Health implications of heavy metals in soil, scalp hair and selected food crops within eldoret municipality, Kenya. IOSR J. Environ. Sci. Toxicol. Food Technol. 2013, 7, 47-55. 
3. Cabral Pinto, M.M.; Marinho-Reis, A.P.; Almeida, A.; Ordens, C.M.; Silva, M.M.; Freitas, S.; Simoes, M.R.; Moreira, P.I.; Dinis, P.A.; Diniz, M.L.; et al. Human predisposition to cognitive impairment and its relation with environmental exposure to potentially toxic elements. Environ. Geochem. Health 2017. [CrossRef] [PubMed]

4. Liu, G.; Yu, Y.; Hou, J.; Xue, W.; Liu, X.; Liu, Y.; Wang, W.; Alsaedi, A.; Hayat, T.; Liu, Z. An ecological risk assessment of heavy metal pollution of the agricultural ecosystem near a lead-acid battery factory. Ecol. Indic. 2014, 47, 210-218. [CrossRef]

5. Shakoor, A.; Naveed, M.; Hayat, K.; Ahmed, Z.; Hussain, T.; Ul Hassan, I. Accumulation of trace metals Pb and ni in water, soil and vegetables grown in suburban areas (a case study). Sci. Int. 2016, 28, 279-286.

6. Aweng, E.R.; Karimah, M.; Suhaimi, O. Heavy metals concentration of irrigation water, soils and fruit vegetables in kota bharu area, Kelantan, Malaysia. J. Appl. Sci. Environ. Sanit. 2011, 6, 237-241.

7. Hang, X.; Wang, H.; Zhou, J.; Ma, C.; Du, C.; Chen, X. Risk assessment of potentially toxic element pollution in soils and rice (Oryza sativa) in a typical area of the Yangtze River delta. Environ. Pollut. 2009, 157, 2542-2549. [CrossRef] [PubMed]

8. Cabral Pinto, M.; Silva, M.; Ferreira da Silva, E.A.; Marinho-Reis, A.P. The cancer and non-cancer risk of Santiago Island (Cape Verde) population due to potential toxic elements exposure from soils. Geosciences 2017, 7, 78. [CrossRef]

9. Tepanosyan, G.; Maghakyan, N.; Sahakyan, L.; Saghatelyan, A. Heavy metals pollution levels and children health risk assessment of yerevan kindergartens soils. Ecotoxicol. Environ. Saf. 2017, 142, 257-265. [CrossRef] [PubMed]

10. Xiao, R.; Wang, S.; Li, R.; Wang, J.J.; Zhang, Z. Soil heavy metal contamination and health risks associated with artisanal gold mining in Tongguan, Shaanxi, China. Ecotoxicol. Environ. Saf. 2017, 141, 17-24. [CrossRef] [PubMed]

11. Liu, G.; Tao, L.; Liu, X.; Hou, J.; Wang, A.; Li, R. Heavy metal speciation and pollution of agricultural soils along jishui river in non-ferrous metal mine area in Jiangxi province, China. J. Geochem. Explor. 2013, 132, 156-163. [CrossRef]

12. Tchounwou, P.B.; Yedjou, C.G.; Patlolla, A.K.; Sutton, D.J. Heavy metal toxicity and the environment. In Molecular, Clinical and Environmental Toxicology; Springer: Basel, Switzerland, 2012; Volume 101, pp. 133-164.

13. Weiss, B. Vulnerability of children and the developing brain to neurotoxic hazards. Environ. Health Perspect. 2000, 108, 375-381. [CrossRef] [PubMed]

14. Titman, P.; Pink, E.; Skucek, E.; O’Hanlon, K.; Cole, T.J.; Gaspar, J.; Xu-Bayford, J.; Jones, A.; Thrasher, A.J.; Davies, E.G.; et al. Cognitive and behavioral abnormalities in children after hematopoietic stem cell transplantation for severe congenital immunodeficiencies. Blood 2008, 112, 3907-3913. [CrossRef] [PubMed]

15. Prasher, D. Heavy metals and noise exposure: Health effects. Noise Health 2009, 11, 141. [CrossRef] [PubMed]

16. Zhuang, P.; Zou, B.; Li, N.Y.; Li, Z.A. Heavy metal contamination in soils and food crops around dabaoshan mine in guangdong, China: Implication for human health. Environ. Geochem. Health 2009, 31, 707-715. [CrossRef] [PubMed]

17. Fang, Y.; Nie, Z.; Liu, F.; Die, Q.; He, J.; Huang, Q. Concentration and health risk evaluation of heavy metals in market-sold vegetables and fishes based on questionnaires in Beijing, China. Environ. Sci. Pollut. Res. 2014, 21, 11401-11408. [CrossRef] [PubMed]

18. Su, H.; Li, Z.; Fiati Kenston, S.; Shi, H.; Wang, Y.; Song, X.; Gu, Y.; Barber, T.; Aldinger, J.; Zou, B.; et al. Joint toxicity of different heavy metal mixtures after a short-term oral repeated-administration in rats. Int. J. Environ. Res. Public Health 2017, 14, 1164. [CrossRef] [PubMed]

19. Hu, B.; Jia, X.; Hu, J.; Xu, D.; Xia, F.; Li, Y. Assessment of heavy metal pollution and health risks in the soil-plant-human system in the Yangtze River delta, China. Int. J. Environ. Res. Public Health 2017, 14, 1042. [CrossRef] [PubMed]

20. Ozmen, H.; Akarsu, S.; Polat, F.; Cukurovali, A. The levels of calcium and magnesium, and of selected trace elements, in whole blood and scalp hair of children with growth retardation. Iran. J. Pediatr. 2013, 23, 125-130. [PubMed]

21. González-Muñoz, M.J.; Peña, A.; Meseguer, I. Monitoring heavy metal contents in food and hair in a sample of young spanish subjects. Food Chem. Toxicol. 2008, 46, 3048-3052. [CrossRef] [PubMed] 
22. Briki, M.; Ji, H.; Li, C.; Ding, H.; Gao, Y. Characterization, distribution, and risk assessment of heavy metals in agricultural soil and products around mining and smelting areas of Hezhang, China. Environ. Monit. Assess. 2015, 187, 767. [CrossRef] [PubMed]

23. Xue, Y.; Yang, L.; Ouyang, Z.; Wei, B.; Yu, J. Relationships between metal concentrations in human hair and in soil, road dust, and rice. Hum. Ecol. Risk Assess. 2014, 21, 1007-1019. [CrossRef]

24. Zhou, H.; Yang, W.T.; Zhou, X.; Liu, L.; Gu, J.F.; Wang, W.L.; Zou, J.L.; Tian, T.; Peng, P.Q.; Liao, B.H. Accumulation of heavy metals in vegetable species planted in contaminated soils and the health risk assessment. Int. J. Environ. Res. Public Health 2016, 13, 289. [CrossRef] [PubMed]

25. The General Administration of Quality Supervision, Inspection and Quarantine of the People's Republic of China. Safety Qualification for Agricultural Product-Safety Requirements for Non-Environmental Pollution Vegetable; The General Administration of Quality Supervision, Inspection and Quarantine of the People's Republic of China: Beijing, China, 2001.

26. Rodushkin, I.; Axelsson, M.D. Application of double focusing sector field icp-ms for multielemental characterization of human hair and nails. Part I. Analytical methodology. Sci. Total Environ. 2000, 250, 83-100. [CrossRef]

27. Ai, S.; Guo, R.; Liu, B.; Ren, L.; Naeem, S.; Zhang, W.; Zhang, Y. A field study on the dynamic uptake and transfer of heavy metals in chinese cabbage and radish in weak alkaline soils. Environ. Sci. Pollut. Res. Int. 2016, 23, 20719-20727. [CrossRef] [PubMed]

28. Song, M.Y.; Liu, J.B.; Zhou, T.F.; Zhou, Z.Y. Chemical speciation of some heavy metals in ningbo urban soil and ecological effects. Chin. J. Soil Sci. 2009, 40, 142-143.

29. Wei, B.; Yang, L. A review of heavy metal contaminations in urban soils, urban road dusts and agricultural soils from China. Microchem. J. 2010, 94, 99-107. [CrossRef]

30. Malan, M.; Müller, F.; Cyster, L.; Raitt, L.; Aalbers, J. Heavy metals in the irrigation water, soils and vegetables in the philippi horticultural area in the western cape province of South Africa. Environ. Monit. Assess. 2014, 187, 4085. [CrossRef] [PubMed]

31. Bolan, N.; Kunhikrishnan, A.; Thangarajan, R.; Kumpiene, J.; Park, J.; Makino, T.; Kirkham, M.B.; Scheckel, K. Remediation of heavy metal(loid)s contaminated soils—To mobilize or to immobilize? J. Hazard. Mater. 2014, 266, 141-166. [CrossRef] [PubMed]

32. Zhang, L.E.; Mo, Z.; Qin, J.; Li, Q.; Wei, Y.; Ma, S.; Xiong, Y.; Liang, G.; Qing, L.; Chen, Z.; et al. Change of water sources reduces health risks from heavy metals via ingestion of water, soil, and rice in a riverine area, South China. Sci. Total Environ. 2015, 530, 163-170. [CrossRef] [PubMed]

33. Liang, G.; Pan, L.; Liu, X. Assessment of typical heavy metals in human hair of different age groups and foodstuffs in Beijing, China. Int. J. Environ. Res. Public Health 2017, 14, 914. [CrossRef] [PubMed]

34. Wilhelm, M.; Ohnesorge, F.K.; Lombeck, I.; Hafner, D. Uptake of aluminum, cadmium, copper, lead, and zinc by human scalp hair and elution of the adsorbed metals. J. Anal. Toxicol. 1989, 13, 17-21. [CrossRef] [PubMed]

35. Martín-Cameán, A.; Molina-Villalba, I.; Jos, A.; Iglesias-Linares, A.; Solano, E.; Cameán, A.M.; Gil, F. Biomonitorization of chromium, copper, iron, manganese and nickel in scalp hair from orthodontic patients by atomic absorption spectrometry. Environ. Toxicol. Pharmacol. 2014, 37, 759-771. [CrossRef] [PubMed]

36. Buononato, E.V.; De Luca, D.; Galeandro, I.C.; Congedo, M.L.; Cavone, D.; Intranuovo, G.; Guastadisegno, C.M.; Corrado, V.; Ferri, G.M. Assessment of environmental and occupational exposure to heavy metals in taranto and other provinces of southern italy by means of scalp hair analysis. Environ. Monit. Assess. 2016, 188, 337. [CrossRef] [PubMed]

37. Afridi, H.I.; Kazi, T.G.; Brabazon, D.; Naher, S.; Talpur, F.N. Comparative metal distribution in scalp hair of pakistani and irish referents and diabetes mellitus patients. Clin. Chim. Acta 2013, 415, 207-214. [CrossRef] [PubMed]

38. Luo, R.; Zhuo, X.; Ma, D. Determination of 33 elements in scalp hair samples from inhabitants of a mountain village of Tonglu city, China. Ecotoxicol. Environ. Saf. 2014, 104, 215-219. [CrossRef] [PubMed]

39. Landrigan, P.J.; Goldman, L.R. Children's vulnerability to toxic chemicals: A challenge and opportunity to strengthen health and environmental policy. Health Aff. 2011, 30, 842-850. [CrossRef] [PubMed]

40. Peña-Fernández, A.; Lobo-Bedmar, M.C.; González-Muñoz, M.J. Monitoring lead in hair of children and adolescents of alcalá de henares, Spain. A study by gender and residential areas. Environ. Int. 2014, 72, 170-175. [CrossRef] [PubMed] 
41. Molina-Villalba, I.; Lacasaña, M.; Rodríguez-Barranco, M.; Hernández, A.F.; Gonzalez-Alzaga, B.; Aguilar-Garduño, C.; Gil, F. Biomonitoring of arsenic, cadmium, lead, manganese and mercury in urine and hair of children living near mining and industrial areas. Chemosphere 2015, 124, 83-91. [CrossRef] [PubMed]

42. Pandya, C.; Pillai, P.; Nampoothiri, L.P.; Bhatt, N.; Gupta, S.; Gupta, S. Effect of lead and cadmium co-exposure on testicular steroid metabolism and antioxidant system of adult male rats. Andrologia 2012, 44, 813-822. [CrossRef] [PubMed]

2018 by the authors. Licensee MDPI, Basel, Switzerland. This article is an open access article distributed under the terms and conditions of the Creative Commons Attribution (CC BY) license (http://creativecommons.org/licenses/by/4.0/). 